University of Nebraska - Lincoln

DigitalCommons@University of Nebraska - Lincoln

Papers in the Earth and Atmospheric Sciences Earth and Atmospheric Sciences, Department

Winter 2005

\title{
Groundwater Irrigation in the Development of the Grand Prairie Rice Industry, 1896-1950
}

John B. Gates

University of Nebraska-Lincoln, jgates2@unl.edu

Follow this and additional works at: https://digitalcommons.unl.edu/geosciencefacpub

Part of the Earth Sciences Commons

Gates, John B., "Groundwater Irrigation in the Development of the Grand Prairie Rice Industry, 1896-1950" (2005). Papers in the Earth and Atmospheric Sciences. 172.

https://digitalcommons.unl.edu/geosciencefacpub/172

This Article is brought to you for free and open access by the Earth and Atmospheric Sciences, Department of at DigitalCommons@University of Nebraska - Lincoln. It has been accepted for inclusion in Papers in the Earth and Atmospheric Sciences by an authorized administrator of DigitalCommons@University of Nebraska - Lincoln. 


\title{
Groundwater Irrigation in the Development of the Grand Prairie Rice Industry, 1896-1950
}

\author{
JOHN GATES
}

ARKANSAS PRODUCES MORE RICE than any other state in the U.S., being responsible for slightly less than half of the total number of acres harvested nationwide. ${ }^{1}$ Much of the state's rice is grown in the Grand Prairie of east-central Arkansas, where the crop serves as the centerpiece of the region's economy. An extremely water-intensive crop, rice in Arkansas requires approximately thirty-three inches of water in a growing season, but the Grand Prairie receives an average of only eleven inches of rain. The remainder must be secured from other sources. As a result, rice production in the Grand Prairie has always been dependent upon irrigation, primarily from groundwater. The necessity of raising groundwater has shaped the development of the industry in the Grand Prairie from its inception and has taken a toll on the region's water resources. Groundwater depletion has been a concern since as early as the 1920s.

This essay hopes to elucidate some of the ways in which groundwater and groundwater irrigation have affected the Grand Prairie's rice industry over time and conversely how the development of the industry has altered the region's groundwater conditions. It will thus concentrate on aspects of the industry's history that have often been overlooked in favor of rice cultivation's social dimensions and consider hydrological systems not just as resources awaiting exploitation or as simple con-

${ }^{1}$ United States Department of Agriculture National Agricultural Statistics Service, "Quick Stats: Agricultural Statistics Data Base," http://www.nass.usda.gov/QuickStats (accessed September 6, 2004).

John Gates is a doctoral candidate at the Oxford Centre for Water Research at the University of Oxford in Great Britain. He thanks Professor W. M. Edmunds, Professor W. B. Gatewood, and the Arkansas Historical Quarterly's two anonymous referees for their helpful comments and suggestions. 
straints on production but as variables whose roles and effects can change over time.

The primary source of irrigation water in the Grand Prairie is the Mississippi River Valley Alluvial Aquifer, a part of the Gulf Coastal Plain Aquifer System. ${ }^{2}$ The aquifer underlies portions of seven states (Illinois, Kentucky, Tennessee, Missouri, Arkansas, Mississippi, and Louisiana) and has a total area of about 32,000 square miles. It consists of water-bearing sands and gravels, mainly from the Pleistocene, that were deposited by the Mississippi and Ohio Rivers and their tributaries. The aquifer has an average thickness of around 100 feet, gradually changing from fine grained at the top to mainly coarse-grained material at the bottom.

Above the aquifer is the Mississippi River Valley confining unit, a layer of clay, silt, and fine sand that is much less permeable to water. This layer, commonly referred to as the clay cap, is thickest in the Grand Prairie, where it is consistently greater than fifty feet. This sub-soil clay layer inhibits irrigation water from draining out of the flooded rice fields, a condition that is advantageous for rice production (though it complicates the task of draining rice fields after the growing season).

Before extensive pumping began, the Alluvial Aquifer exhibited artesian conditions in all or most of the Grand Prairie, which means water levels observed in wells were several feet higher than the aquifer itself. In this region, groundwater discharged from the aquifer chiefly to rivers, particularly the White, Arkansas, Little Red, and Bayou Meto. Recharge sufficient to offset the losses was supplied by rainfall and, to a lesser extent, through interaction with the underlying rock. Because of the location of the major rivers to the south and east, the general direction of groundwater flow was towards the southeast, mirroring the general slope of the land surface.

Rice cultivation in the Grand Prairie is usually traced to W. H. Fuller, who in 1895 had moved from Nebraska to the vicinity of Carlisle, Lonoke County. ${ }^{3} \mathrm{He}$ was one of a large number of northern and

${ }^{2}$ This summary of the Grand Prairie's hydrogeology is drawn from: D. J. Ackerman, "Hydrology of the Mississippi River Valley Alluvial Aquifer, South-Central United States," U.S. Geological Survey Professional Paper 1416-D (1996); Kyle Engler, D. G. Thompson, and R. G. Kazmann, "Ground Water Supplies for Rice Irrigation in the Grand Prairie Region, Arkansas," Arkansas Agricultural Experiment Station Bulletin 457 (June 1945): 29-35.

${ }^{3}$ See, for example, Ernest E. Sampson, "Half a Century on Grand Prairie," Arkansas Historical Quarterly 14 (Spring 1955): 36-37. There is evidence, however, of some earlier small-scale rice farming in the Grand Prairie. See, for example, Thomas Nuttall, A Journal of Travels into the Arkansa Territory, during the year 1819, with Occasional Observations on the Manners of the Aborigines (Philadelphia: Thos. M. Palmer, 1821), 116. 
midwestern farmers attracted to the sparsely populated Grand Prairie by low land prices and an accessibility newly afforded by railroad lines. In August 1896, Fuller and a companion, Hewit Puryear, traveled via horse and wagon to Louisiana for a hunting trip. Along the way, the pair encountered rice fields near the town of Crowley in southern Louisiana. Fuller recalled in 1909 that he paused there for several hours to observe the rice fields and pumping plant, the first he had ever seen. He realized the conditions under which rice was grown in the area were similar to those existing in the Grand Prairie. "It convinced me we had a good rice country if we had the water. At that time there were no wells [near Crowley] but they were talking of making wells, which gave me the idea of wells here." 4

Fuller, with rice seed from Louisiana, returned to Carlisle, installed two four-inch diameter wells, and planted three acres of rice. He reported that the plants flourished until he "pulled [his] pump to pieces." Despite this temporary setback, the experiment convinced Fuller of the potential rice cultivation held for the Grand Prairie. In 1898, accompanied by John Morris, another Grand Prairie farmer from Nebraska, he returned to Louisiana to master the techniques of rice production. Fuller apprenticed for four years before returning Arkansas in 1903. Upon his return, he convinced a group of local businessmen to pledge $\$ 1,000$ to cover his initial expenses, provided that he harvested at least thirty-five bushels per acre. ${ }^{5}$

The following year, he installed a new pump and sowed seventy acres with rice, from which he eventually harvested 5,225 bushels. Two other farmers also harvested rice in the Grand Prairie that year, one of whom was Emma Morris, the widow of John Morris, who had died while in Louisiana. ${ }^{6}$

This success convinced others that the region was suitable for rice production. By the time Fuller harvested his 1904 crop, the University of Arkansas Agricultural Experiment Station had begun conducting rice research on a plot near Lonoke. Sections of prairie land soon began selling more rapidly, and large areas of natural prairie were plowed for the first time. In 1906, roughly 4,000 acres of rice were harvested, almost all of which was irrigated with groundwater. Agricultural historian Pete Daniel writes that most farmers harvested around fifty-five to sixty

\footnotetext{
${ }^{4}$ William H. Fuller, "Early Rice Farming on Grand Prairie," Arkansas Historical Quarterly 14 (Spring 1955): 72.

${ }^{5}$ Ibid., $72-73$.

${ }^{6}$ Ibid., 74; Henry C. Dethloff, A History of the American Rice Industry, 1685-1985 (College Station: Texas A\&M University Press, 1988), 84-86.
} 


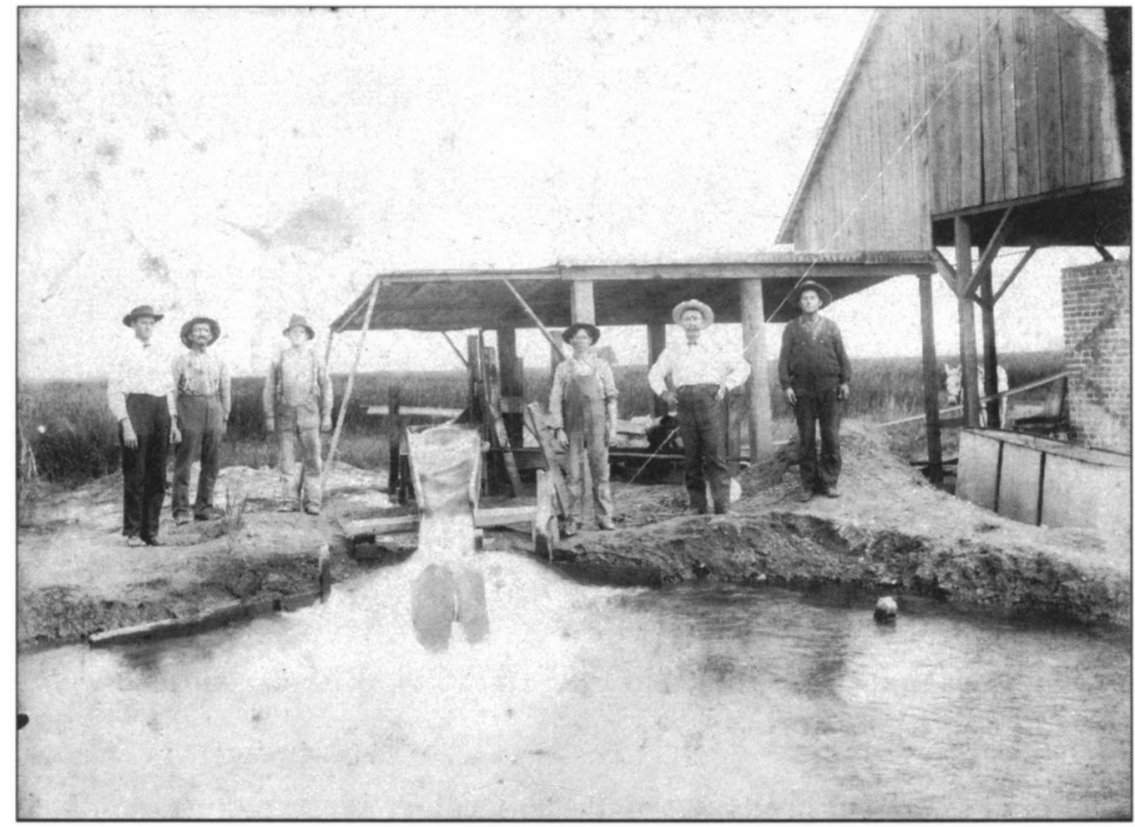

Early Grand Prairie irrigators, 1906. Courtesy Museum of the Grand Prairie, Stuttgart, AR.

bushels per acre that year, and, except for those who bought cheap pumps that quickly failed, success was more common than failure. ${ }^{7}$ With market prices approaching $\$ 1.00$ per bushel, farmers realized substantial profits, prompting a variety of rice-related businesses to enter the area. The region's first mill, the Stuttgart Rice Mill, opened in October 1907, yielding an inaugural season's profit of $\$ 16,000$. Within only two years, local output exceeded its capacity, and a second mill was erected nearby. Layne \& Bowler Company, experts in wells and pumps whose slogan was "Water or No Pay," also opened for business in Stuttgart in $1907 .^{8}$

Local landowners and businesses soon initiated campaigns to promote rice farming in the Grand Prairie. The Arkansas Gazette boasted of the area's inexpensive farmland and high rice market prices. ${ }^{9}$ One of the largest private landowners in the region, the St. Louis Southwestern Railway,

${ }^{7}$ Pete Daniel, Breaking the Land: The Transformation of Cotton, Tobacco, and Rice Cultures since 1880 (Urbana: University of Illinois Press, 1985), 48.

${ }^{8} \mathrm{~J}$. M. Spicer, Beginnings of the Rice Industry in Arkansas (Stuttgart, AR: Arkansas Rice Promotion Association, 1964), 25.

${ }^{9}$ Arkansas Gazette (Little Rock), July 14, 1906. 


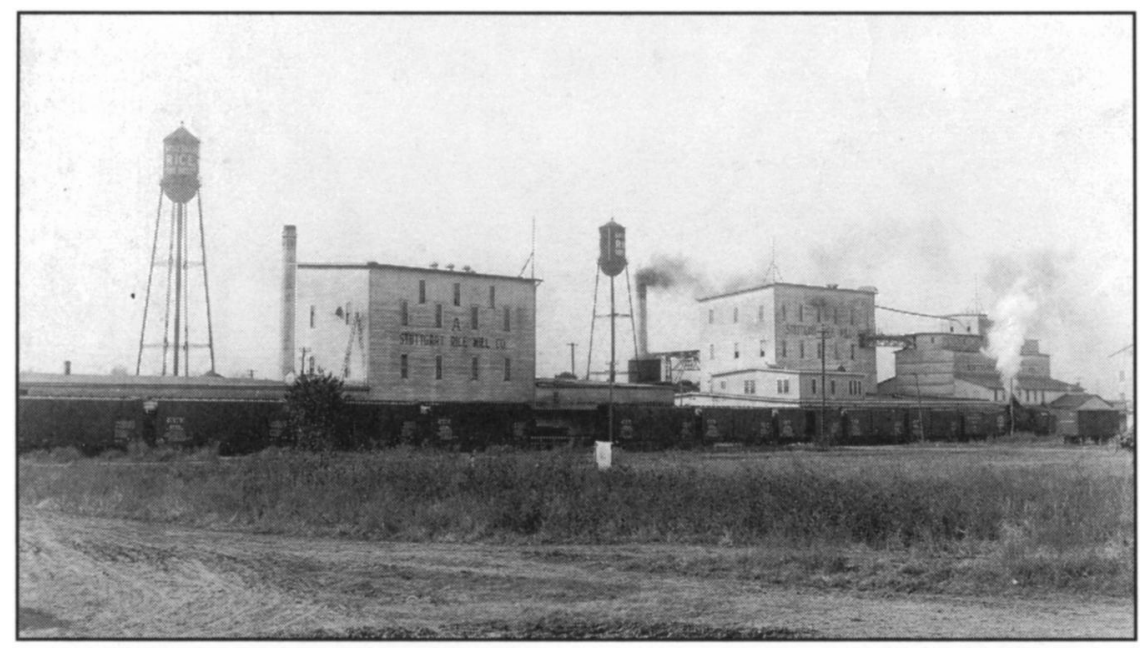

Stuttgart rice mills, constructed in 1907 and 1909. Courtesy Museum of the Grand Prairie, Stuttgart, AR.

used the excitement generated by these developments to attract potential land buyers. The company regularly offered reduced-fare excursions to the area for those interested in purchasing land. It published a promotional booklet in 1908 offering accounts of local success and profit, such as that of Mr. T. Hein: "I had 45 acres in rice which gave a yield of 3,300 bushels. The rice I sold to the rice mill in Stuttgart and was paid \$3,326.80, cash. Besides this I retained 120 bushels for seed for next year. Outside my own work the actual cash expense for labor, fuel, twine, threshing, etc., amounted to $\$ 400 . " 10$

Such success depended on the availability of sufficient water. Fuller's travel to Louisiana in 1896 had coincided with some of the first uses of pumps to supply water to those fields. Earlier, rice had been watered exclusively from rain captured in small reservoirs, a technique aptly referred to as the "Providence" method, since the success of the crop was closely tied to how much it rained in the spring and summer. ${ }^{11}$ A regional drought in 1893 and 1894 exposed the weakness of this method and prompted experimentation with the pumping of water from nearby bayous uphill into canals that fed the fields. By 1896, such pumping had gained widespread favor. Fuller also noted in his 1909 manuscript that although there had

${ }^{10}$ E. W. LaBeaume, Arkansas Rice: Its Growth and Possibilities along the Cotton Belt Route (St. Louis: St. Louis Southwestern Railway Co., 1908), 15.

${ }^{11}$ Daniel, Breaking the Land, 41. 
been no irrigation wells around Crowley at that time, their construction was being considered. In subsequent years, many farmers whose rice was too far from the bayous, finding that extensive canal building and pumping was expensive, turned to groundwater as a more economical and reliable water source. Since household pumps were common in the Grand Prairie by that time, Fuller must have known that groundwater could be obtained there. ${ }^{12}$

Up to this point, groundwater use in the Grand Prairie had been limited to household consumption and small-scale irrigation of cotton and vegetables. Groundwater levels in the Alluvial Aquifer varied somewhat throughout the region. In general, water could be reached at a depth of 150 feet or less and in some places at as little as 30 feet. Household wells were typically operated with hand pumps, while water for irrigation was raised by wind power. The existence of a windmill manufacturing company in Stuttgart in the 1890 s attests to the fact that such irrigation wells were not uncommon. ${ }^{13}$

By the 1910 growing season, the Alluvial Aquifer provided water for 46,500 of the 48,000 acres of Grand Prairie rice being irrigated. Most of the other 1,500 irrigated acres were close enough to rivers and streams to rely entirely on them. The Rice Journal had proclaimed the preceding year that "Prairies which were formerly idle now send up smoke from almost countless chimneys and the exhaust from countless engines pumping water declare a new era."14

For Grand Prairie rice farmers, groundwater retrieval, being in some ways the most critical aspect of the production process, demanded considerable skill and capital. Before the mechanization of the harvest process, the water pump, along with its power source, was among the most complex machinery on the farm.

The raising of water from the aquifer first required the digging of a well of adequate depth and circumference. Typical well shafts had diameters of eighteen to twenty-four inches and were constructed with wooden boards, concrete, or, in later years, steel. Lined by fine metal screens, the well would extend below the water table into the saturated sands and gravels of the Alluvial Aquifer for another twenty feet or so, depending on local conditions. All told, this required the removal of about 270 square feet of

\footnotetext{
${ }^{12}$ Fuller, "Early Rice Farming on Grand Prairie," 72; Dethloff, History of the American Rice Industry, 78.

${ }^{13}$ Annual Meeting of the Stuttgart Fair Association 6 (1895): 29.

${ }^{14}$ Quoted in Daniel, Breaking the Land, 48.
} 


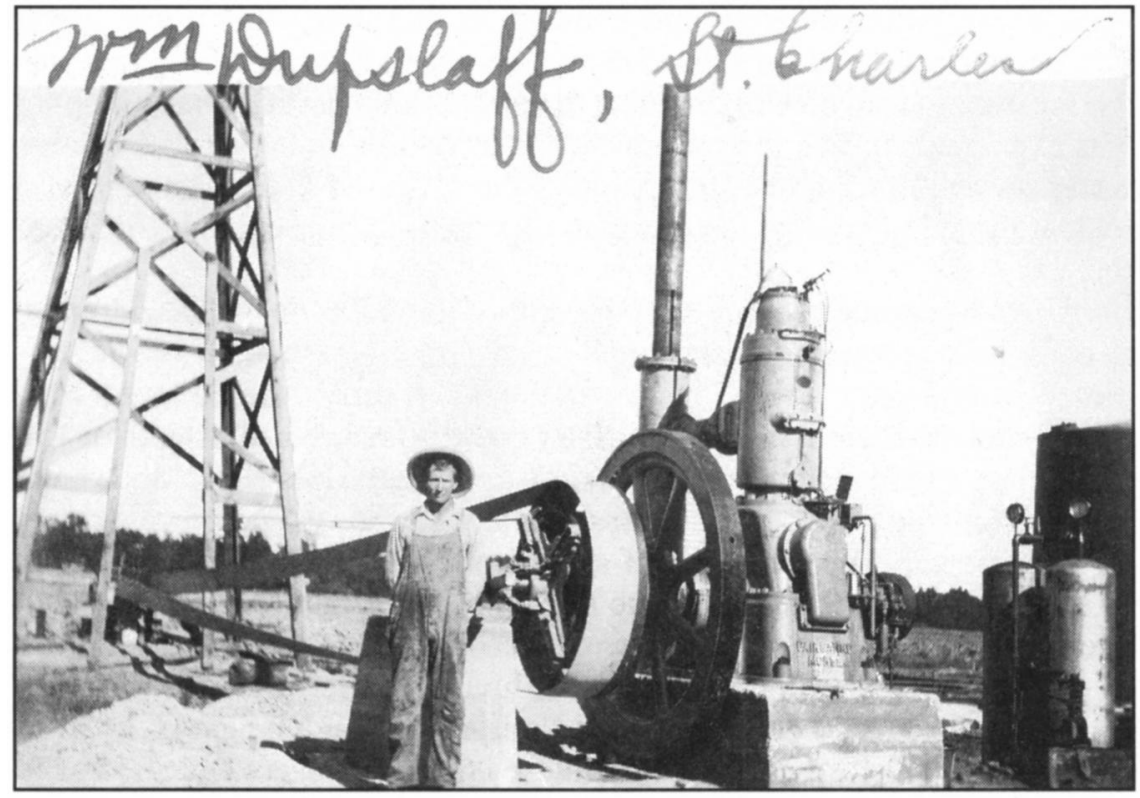

Rice farmer William Dupslaff of St. Charles with steam-powered pump and well equipment. Courtesy Museum of the Grand Prairie, Stuttgart, AR.

clay, sand, and gravel from depths as much as 170 feet below the surface. Typically, tall wooden derricks would be set up above the well site to aid in drilling. The derricks were left standing after construction because of the likelihood that further maintenance would be necessary. Once the well was completed, a centrifugal pump was placed a few feet below the water level. Powered by wood-fueled steam engines capable of producing eighteen or twenty horsepower, the first pumps could raise more than 400 gallons per minute if properly installed and maintained. By 1908, pumps had become more efficient, with some farmers reporting yields of 1,500 gallons per minute, sufficient to irrigate 200 acres. $^{15}$

As essential as groundwater retrieval was, the operation of such equipment was not within most farmers' realm of expertise. The majority initially had no knowledge of the technical aspects of groundwater irrigation, whether digging wells or maintaining steam engines. Such irrigation-related tasks were often carried out through a costly process of trial and error. $^{16}$

${ }^{15}$ LaBeaume, Arkansas Rice, 17.

${ }^{16}$ Ralph Desmarais and Robert Irving, The Arkansas Grand Prairie (Stuttgart, AR: Arkansas County Agricultural Museum, 1983), 19. 
Not only was water pumping the most technologically challenging aspect of rice farming, it often required the greatest initial investment. Before tractors, trucks, and other heavy machinery raised the ante for entering the rice business, the installation and use of a well and pump was the most costly element apart from the land itself. One of the first irrigation wells in the Grand Prairie, at the Arkansas Agricultural Experiment Station, reportedly cost $\$ 456.00$, with an additional $\$ 858.59$ for the pump and installation - this at a time when land was selling at about $\$ 70.00$ per acre. ${ }^{17}$ Farmer J. P. Rich of Stuttgart wrote in 1908 that his well cost $\$ 2,114.52$ and pumping machinery $\$ 1,450.00$. Not including fuel and maintenance expenses, this amounted to an initial cost of $\$ 17.82$ per acre to irrigate his 200 acres. ${ }^{18}$ The high initial outlay required to obtain irrigation water contributed to the prevalence of investor ownership of farms. Some would-be rice farmers, especially those without access to credit, could not afford to go into business themselves and had to rent irrigated land. Tenancy arrangements, however, were never as harsh as those experienced by nearby cotton sharecroppers. The high cost of irrigation equipment also encouraged economies of scale in the form of larger farms, since a single well was capable of irrigating large tracts.

Early on, Grand Prairie farmers seemed to assume that an infinite reservoir of water existed below the prairie. One report emphasized that the region enjoyed an "inexhaustible supply of pure water," while another promised that the "inexhaustible" supply allowed "each grower absolute independence from every other grower." 19 This fresh water, and the monetary wealth it promised, was free for the taking to those who could manage to lift it.

In only twelve years, however, the rice industry of the Grand Prairie began to use up its seemingly bottomless water supply. While the continuous cultivation of rice had benefited farmers and businessmen, it had taken its toll on the prairie soils. The crop's high demand for nitrogen had reduced soil fertility, and yields began a slow decline by $1910 .^{20}$ Farmers responded by increasing the number of acres under the plow, and the amount of irrigated land increased from 57,000 acres in 1911 to

${ }^{17}$ Spicer, Beginnings of the Rice Industry, 20.

${ }^{18}$ LaBeaume, Arkansas Rice, 17.

${ }^{19}$ Grand Prairie Rice Lands (Stuttgart, AR: Kocourek \& Wilken and Herald Printing Company, 1910), pamphlet in the collection of the Museum of the Grand Prairie, Stuttgart, AR; LaBeaume, Arkansas Rice, 33.

${ }^{20}$ William Gay, "From Family Farm to Big Business: The Evolution of the Arkansas County Rice Industry, 1920-1994" (master's thesis, University of Arkansas, Fayetteville, 1998), 9. 
100,000 in 1916. 93,000 of these acres drew water from the Alluvial Aquifer. Modern estimates suggest that in Arkansas one acre of rice requires on average 1.8 acre-feet of irrigation during the course of a growing season. By this measure, 167,400 acre-feet of water were withdrawn from the aquifer in 1916. Thus, based upon current knowledge of Alluvial Aquifer recharge rates, extraction from the aquifer exceeded natural recharge for the first time that year. ${ }^{21}$ Between 1905 and 1916, irrigators had pumped a total of 970,000 acre-feet from the aquifer.

Throughout the second decade of Grand Prairie rice cultivation, pumping plants continued to pour forth with abundance, and technological developments steadily improved the process. Diesel and semi-diesel oil engines had replaced the less efficient steam engines for powering water pumps, and a few pumps were already run by electricity. The dependability and affordability of the first Fordson model made the tractor a widely accessible tool by 1918 . Farm trucks could be seen amongst horses and wagons hauling rice to the mills. ${ }^{22}$ Since World War I had driven up market prices and profits, many farmers spent savings or borrowed money for such improvements.

In 1920, farmers poised themselves for another year of huge returns by investing in more land, wells, and equipment. The result was a recordbreaking yield, with 5,550,000 bushels harvested in Arkansas County alone. Groundwater use similarly broke records, with 256,000 acre-feet extracted from the Alluvial Aquifer, a mark that would not again be reached for another twenty-four years. ${ }^{23}$ But instead of the stratospheric prices of the previous two harvests, the price of the first rice of the season to be milled dropped to $\$ 1.25$ per bushel, and the market soon bottomed out at $\$ 0.30$ per bushel.

The crash had enormous repercussions in the Grand Prairie. The season's returns repaid little of the investments made in the previous few years, and a large percentage of small farms fell delinquent by September $1921 .{ }^{24}$ Farmers tried to adjust, some selling off or mortgaging tracts of land. Cooperative organizations were formed, most prominently the Arkansas Rice Growers' Cooperative Association, now

${ }^{21}$ Kyle Engler, F. H. Bayey, and R. T. Sniegocki, "Artificial Recharge, Grand Prairie Region, Environment and History," Geological Survey Water-Supply Paper 1615-A (1963): 16, 20-21; Ackerman, "Hydrology of the Mississippi River Valley Alluvial Aquifer," 32 .

${ }^{22}$ Grand Prairie News (Stuttgart), June 20, 1918; Spicer, Beginnings of the Rice Industry, 52-54.

${ }^{23}$ Rice Millers' Association, Annual Acreage Report (1920), folder 1, box 99, Rice Millers' Association Records, Special Collections Division, University of Arkansas Libraries, Fayetteville.

${ }^{24}$ Grand Prairie News, May 26, 1921. 
Riceland Foods, which stabilized prices by joint marketing. Many, however, could not overcome the loss. The number of farms fell significantly, as did total acres, from 149,000 in 1920 to 112,000 the following year. ${ }^{25}$ Alluvial Aquifer groundwater extraction for 1921 fell to 189,000 acre-feet, a much lower, though still unsustainable, rate. By 1922 , prices had stabilized at around $\$ 1.00$ per bushel, where they would stay for the next decade. Gone were the days when a small rice field and a well could guarantee one a sufficient income. Many sold their farms and moved to the region's growing towns. Those who remained enlarged their holdings. Before 1921, farms maintaining more than 500 acres were scarce. In 1940, more than 100 of them could be found in the Grand Prairie. ${ }^{26}$

The continuing importance of groundwater resources to the region's chastened economy was not lost on the people of the Grand Prairie. A booklet published for the tenth annual Arkansas Rice Carnival in Stuttgart in October 1928 included an article on pumping equipment entitled "The Heart Throbs of the Rice Belt." The first paragraph began, "I am indebted to Mr. Walter Kennedy of the Grand Prairie Leader for the poetic thought that the regular exhaust explosions of a great oil engine are the heart throbs of the Rice Land. And I would add, that the gushing streams of water delivered by the pumps are great arterial floods of life giving fluid drawn from the ample bosom of Mother Earth."27

For most farmers, such poetic reminders were superfluous. They never lost sight of their dependence on water. For instance, after an installation or repair of pump equipment, it was common for farmers to sleep within earshot of the pump, listening for any interruptions in the rhythmic heart throbs. Since pump failure could spell disaster, rice farmers took these mechanical heartbeats as seriously as they did their own.

In the mid 1920s, a few farmers became concerned when they noticed a persistent drop in their well levels. Groundwater levels fluctuated from week to week and season to season. Even without pumping, they could vary by tens of feet within a given year, influenced by rainfall, river stage, and barometric pressure. So it is not surprising that it took several years to discern the prolonged downward trend, which

\footnotetext{
${ }^{25}$ Daniel, Breaking the Land, 59-60.

${ }^{26}$ Gay, "From Family Farm to Big Business," 69-70.

${ }^{27}$ G. G. Sampson, "The Heart Throbs of the Rice Belt: Evolution of the Irrigation Plant of the Grand Prairie," in 10th Annual Arkansas Rice Carnival (Stuttgart, AR: n.p., 1928).
} 
likely began before 1920 . That rice farmers chose to express their concerns directly to Thaddeus Caraway, U.S. senator from Arkansas, testifies to their alarm. After receiving word from the farmers, Caraway took the matter to officials at the U.S. Geological Survey (USGS) in April 1927. The USGS and Arkansas Geological Survey drew up plans for an investigation into the groundwater resources of the Grand Prairie region, with costs to be shared by both organizations as well as the Stuttgart Chamber of Commerce. Led by USGS scientist David G. Thompson, the study commenced in $1928 .{ }^{28}$ A lengthy open letter from Oscar Meinzer, a prominent hydrogeologist from the USGS, published on the front page of the Grand Prairie Leader in February 1928 explained the justification for and methodology of the study: "The heavy pumping in this district has resulted in a persistent lowering of the water level in the wells. Although there is no serious danger of any sudden exhaustion of the ground water supply, there is a serious question of ultimate depletion and it is undoubtedly very desirable that a thorough investigation be made of the ground water supply of the area."29

The dropping water levels increased the cost of irrigation, which often remained the greatest single expense in the production process. One researcher found that the cost of water in 1928 varied from $\$ 8.03$ to $\$ 17.38$ per acre. ${ }^{30}$ One of the variables was the cost of fuel, which increased with the distance that water had to be raised. So when water levels dropped more than a few feet, not only was it necessary to lower the pump, it also became more expensive to pump on an ongoing basis. $^{31}$

The falling water levels compounded the troubles created by low rice prices. In 1929 , with the price of rice hovering around $\$ 0.90$ per bushel, irrigated acreage hit a six-year low at 129,000. At the same time, falling water levels made it difficult for some farmers to obtain credit. Because of uncertainty about the future of irrigation, the Federal Land Bank and Farm Credit Association refused to make loans to farmers in certain areas. ${ }^{32}$

\footnotetext{
${ }^{28}$ U.S. Geological Survey, Ground-water Supplies for Rice Irrigation in the Grand Prairie Region, Arkansas (Washington: U.S. Department of Interior, 1931), 2; Arkansas Democrat (Little Rock), January 25, 1931.

${ }^{29}$ Grand Prairie Leader (Stuttgart), February 16, 1928.

${ }^{30}$ B. S. Clayton, "Cost of Pumping and Duty of Water for Rice on the Grand Prairie of Arkansas,” Arkansas Agricultural Experiment Station Bulletin 261 (May 1931): 28.

${ }^{31}$ Grand Prairie News, June 20, 1918, December 16, 1920, February 2, 1928.

${ }^{32}$ Engler, Bayley, and Sniegocki, "Artificial Recharge, Grand Prairie Region, Environment and History," 16, 23-24.
} 


\section{Grand Prairie Groundwater Levels}

Example from well location SE1/4 NW1/4, Sec. 23, T. 4S, R. 4W

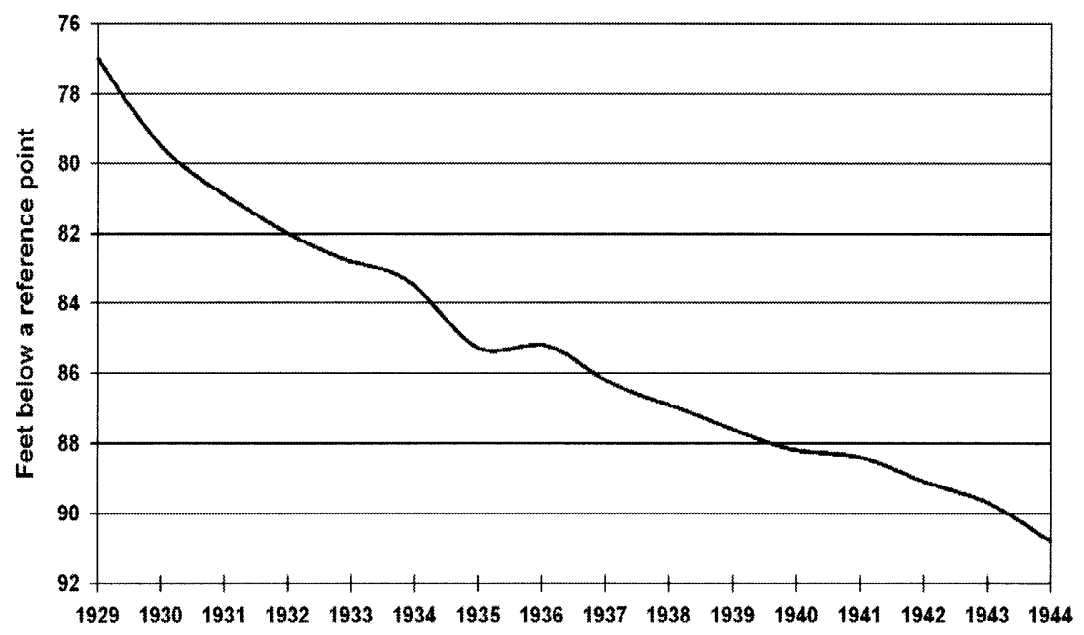

Source: J. R. May, Water Resources Data for Arkansas: Ground-Water Records for Arkansas County (Little Rock: U.S. Geological Survey and Arkansas Geological Commission, 1968).

In the short term, though, the aquifer saw rice farmers through natural disaster. The summer of 1929 was very dry throughout eastern Arkansas and the delta, with June, July, and August rainfall totaling only 5.72 inches in Stuttgart rain gauges, while the forty-year average at that time was 11.57 inches. It had been years since so little precipitation had fallen during the growing season. Despite this, the maturing rice plants of the Grand Prairie seemed to be in prime condition. ${ }^{33}$ Farmers simply kept their pumps running longer.

Instead of returning to normal conditions the following year, the drought not only continued but became more severe. The Drought of 1930 affected much of the southern U.S., but the Mississippi Delta region was by far the hardest hit. The effect on cotton producers in the delta was severe, with the lack of rainfall resulting in dry and shriveled crops and sharply reduced incomes. ${ }^{34}$

${ }^{33}$ Grand Prairie Leader, July 4, 1929.

${ }^{34}$ Nan Woodruff, As Rare as Rain: Federal Relief in the Great Southern Drought of 1930-31 (Urbana: University of Illinois Press, 1985). 
But even as many nearby cotton farmers lost entire crops, the Grand Prairie rice fields remained green and flooded in preparation for an average or better harvest. The intense heat and lack of rainfall tested pumps, requiring them to run continuously for days, but major failures were unusual. The essential difference between the experience of cotton and rice farms during the 1930 drought was simply that the Grand Prairie rice farms already had numerous high-yield wells in use, owing to the high moisture requirements of rice. Few cotton growers of the delta could meet the initial costs of wells and pumps in 1930, nor, given the scale of the project, could they simply install a well at the first sign of dry weather. That year, Arkansas cotton farmers produced 48 percent of normal yield, while both soybeans and corn were total losses. Grand Prairie rice enjoyed an above average harvest of $8,218,000$ bushels with a total value of $\$ 6,492,000 .^{35}$

But the combination of low natural groundwater recharge due to the extremely dry weather, heavy pumping, and high evaporation rates caused well levels to fall approximately 1.8 feet in 1930, about twice the rate of previous years. ${ }^{36}$ The following year, the USGS reported the initial findings of its Grand Prairie groundwater study in the form of a memorandum for the press. By measuring about 150 wells, the researchers discovered that a large oval-shaped trough in water levels had developed. This elongated trough, now referred to as a cone of depression, already encompassed most of the Grand Prairie, with its major axis oriented northwest to southeast and centered between Stuttgart and Almyra in Arkansas County. Researchers also concluded that its position and orientation closely reflected the pattern of pumping. ${ }^{37}$

These results clearly showed how the region's groundwater flow patterns had been significantly altered. While the pre-development direction of groundwater flow was toward the southeast, by 1929 the flow in the southeastern portion of the Grand Prairie had been reversed, converging toward a point near Stuttgart. The area's rivers were losing water to the Alluvial Aquifer, whereas before they were supplied by it. In

\footnotetext{
${ }^{35}$ U.S. Department of Agriculture Division of Livestock Estimates, Arkansas Crops and Livestock Annual Report 1939 and Statistical Summaries 1925-1939 (Little Rock: U.S. Department of Agriculture, 1939), 12; Deane G. Carter and Kyle Engler, "Problems of Water Resources for Rice Irrigation," Arkansas Agricultural Experiment Station Bulletin 371 (February 1939): 3.

${ }^{36}$ Carter and Engler, "Problems of Water Resources for Rice Irrigation," 17.

${ }^{37}$ U.S. Geological Survey, Ground-water Supplies for Rice Irrigation, 12; Engler, Thompson, and Kazmann, "Ground Water Supplies for Rice Irrigation," 29-35.
} 


\section{Irrigated Area and Groundwater Extraction}

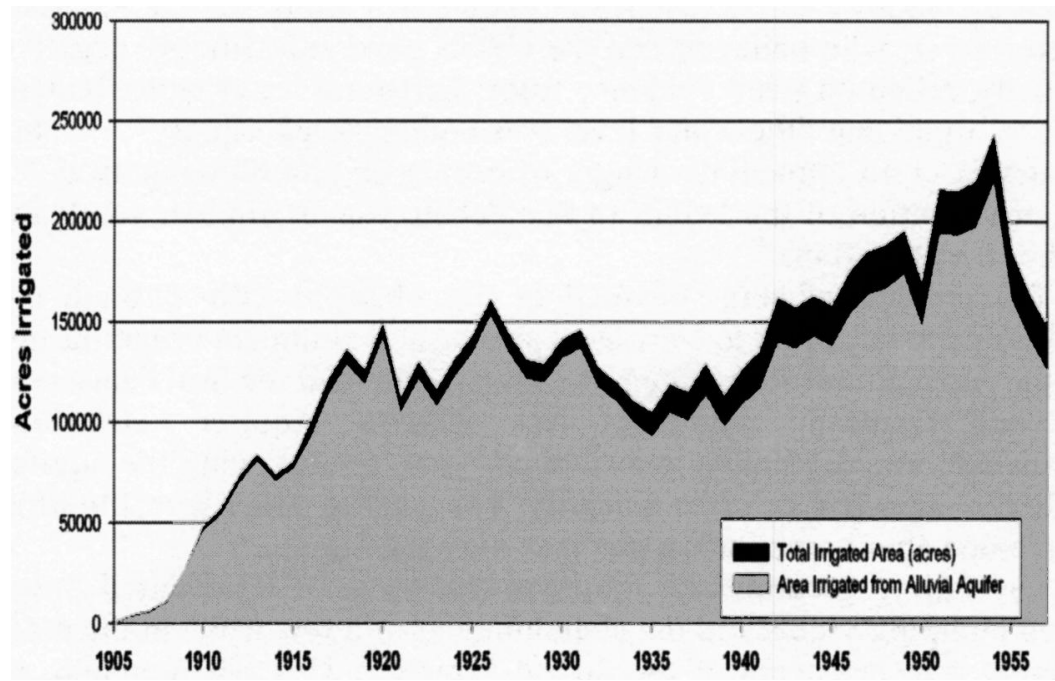

Source: Kyle Engler, F. H. Bayey, and R. T. Sniegocki, "Artificial Recharge, Grand Prairie Region, Environment and History," Geological Survey WaterSupply Paper 1615-A (1963).

most areas, groundwater was no longer under artesian pressure, and water levels near the center of the trough had fallen as much as thirty feet in thirteen years.

The 1931 report was the first scientific verification of groundwater overdraft in the Grand Prairie, although anecdotal evidence in the form of falling water tables had been available for some time. While stopping short of making detailed predictions, the report accurately described the gradual depletion of the region's groundwater.

The release of the USGS memorandum, together with the precipitous drop in well levels caused by the drought, spurred a significant amount of debate around the issue of groundwater depletion. In January 1931, the Arkansas Democrat published a front-page article on the issue. ${ }^{38}$ At the time, most of the public debate focused on the remedial options listed in the memorandum, including artificial recharge (channeling of surface water directly into the aquifer), substitution of surface water for groundwater, use of water from the deeper Sparta

${ }^{38}$ Arkansas Democrat, January 25, 1931. 
Sands (another aquifer that lay beneath the Alluvial Aquifer at a depth of approximately 1000 feet), legal restrictions on groundwater extraction, and the substitution of other crops for rice. Some, however, questioned the validity of the scientists' claims. An editor for the Stuttgart Arkansawyer, who believed that the USGS gave unjustifiably negative publicity, relied on scant evidence from short-term water table fluctuations to argue that "the water level was coming back rapidly. . . . This country is in no immediate danger of drying up and blowing away." 39 The contribution of the USGS to this debate was to allocate funds for further investigations. ${ }^{40}$

The number of acres devoted to rice changed little through the 1930 s, due in large part to New Deal pricing and allotment programs under the Agricultural Adjustment Administration and the Soil Conservation and Domestic Allotment Act. Alluvial Aquifer extractions fluctuated around 200,000 acre-feet per year, overdrawing the aquifer by 50,000 acre-feet or more annually. This caused water levels to drop on average about nine inches per year over the region. ${ }^{41}$

The falling groundwater tables in the early 1930s resulted in reduced pumping yields and the abandonment of a few wells in the most severely affected areas of the Grand Prairie. ${ }^{42}$ This phenomenon, in combination with the increasing costs of raising water, turned some farmers toward surface sources for their irrigation needs. Previously, only a few farmers who owned land adjacent to streams and rivers had used surface water for irrigation. By 1910, several fields were irrigated with river water pumped from three small reservoirs, one on Bayou Meto and two on the White River. The first fully enclosed reservoir in the Grand Prairie was put into operation by $1926 .{ }^{43}$

Farmers placed the first rain-fed reservoirs in low-lying areas, usually with poor drainage and of little value for rice cultivation. Since no land was taken out of production and the costs of construction and pumping were relatively low, rain-fed reservoirs became an inexpensive option for farmers. However, their operation came with other liabilities. Inexperienced with surface water irrigation, farmers had to learn by trial and error techniques for minimizing evaporation, which can exceed fifteen inches over a summer. Also, the naturally suitable reservoir sites

${ }^{39}$ Arkansawyer (Stuttgart), June 25, 1931.

${ }^{40}$ Grand Prairie Leader, January 2, 1930.

${ }^{41}$ Daniel, Breaking the Land, 134-138; K. Engler, "Water Levels in Rice Irrigation Wells in the Grand Prairie Region," Arkansas Farm Research 7 (May-June 1958): 12.

${ }^{42}$ Engler, "Water Levels in Rice Irrigation Wells," 12.

${ }^{43}$ Spicer, Beginnings of the Rice Industry, 22-23. 
sometimes spilled over property lines, causing disagreements and even legal disputes. ${ }^{44}$ Still, by 1937 , twenty-four enclosed reservoirs encompassing 5,964 acres were in use in the Grand Prairie. They were capable of irrigating approximately 7,300 acres. ${ }^{45}$ But, compared to the more than 100,000 acres irrigated by groundwater, their overall contribution remained minor.

In the 1930 s, some irrigators near the center of the cone of depression, whose wells were no longer supplying sufficient quantities of water, turned increasingly to deep wells, raising water from the Sparta Sands Aquifer at depths of approximately 1,000 feet. Such installations cost far more than those for Alluvial Aquifer wells, and the expense of pumping from a deep well was also higher. In 1929, a deep well installation cost $\$ 7,000$, compared to $\$ 1,000$ or $\$ 2,000$ for a shallow one. ${ }^{46}$ Accordingly, deep wells were considered only if there was no expendable land on which to create a rain-fed reservoir.

While many irrigators adjusted to changing conditions on an individual basis, several groups and organizations looked for regional solutions to the problem of groundwater depletion, now an unambiguous threat. In the winter of 1940 , a preliminary hearing addressing the need for state water laws was held at the Riceland Hotel in Stuttgart. ${ }^{47}$ Chaired by State Planning Board engineering director L. A. Henry, the hearing was attended by local rice farmers and others who heard reports from David Thompson of the USGS, United States Department of Agriculture (USDA) economist Wells Hutchins, and a member of the State Planning Board. Thompson emphasized the severity of the situation, and none of the participants questioned the validity of his report. Many of the attendees showed interest in the idea of enacting water laws to limit extraction. Most of the farmers' questions concerned the relative merits of the water rights systems discussed at the hearing, in particular appropriative versus ownership-based (riparian) systems. After this initial meeting, the State Planning Board conducted some further inquiries into the subject of laws to govern groundwater use. However, this early interest in regulatory solutions did not yield new law.

\footnotetext{
${ }^{44}$ See, for example, A. G. Meehan to Heber Core, January 24, 1941, folder 4, box 47 , Core Family Papers, Special Collections Division, University of Arkansas Libraries, Fayetteville.

${ }^{45}$ Carter and Engler, "Problems of Water Resources for Rice Irrigation," 24-25.

${ }^{46}$ U.S. Geological Survey, Ground-water Supplies for Rice Irrigation, 18-19.

${ }^{47}$ Transcript: Preliminary Hearing for Legislation of Water Laws for the State of Arkansas: Stuttgart, Arkansas, January 14, 1940 (Fayetteville: University of Arkansas, College of Agriculture, 1940).
} 
Groundwater regulation in the state of Arkansas only came about in 1992 , and rules governing extraction are still relatively weak. ${ }^{48}$

Other notable early attempts at regional solutions included plans for large reservoirs and artificial groundwater recharge. Scarcity of land hindered the creation of reservoirs large enough to slow groundwater withdrawals, since small on-farm reservoirs had already been built in most areas not suitable for rice and farmers feared taking valuable land out of production. Artificial recharge had been suggested by the USGS as early as 1931, and the USGS and Arkansas Agricultural Experiment Station scientists studied this option further in subsequent years. After extensive research, the scientists deemed these techniques to be both prohibitively costly and unsuitable for local geological conditions. ${ }^{49}$

Arkansas's rice industry fared well during World War II. With disruptions in Asian production, the USDA called upon growers to increase production, supporting prices of up to $\$ 2.50$ per bushel, encouraging the use of the newly introduced combine, and even penalizing farmers for not planting up to allotted acreage. ${ }^{50}$ In 1944, Grand Prairie rice farmers taking advantage of these incentives planted a record 163,000 acres, only 20,000 of which were watered by surface sources. Five years later, the total irrigated acres of rice would reach 195,000, nearly a 73 percent increase over the course of a decade. Water from the Alluvial Aquifer irrigated 88 percent of these acres. ${ }^{51}$

By 1944, the boundaries of the cone of depression in the Alluvial Aquifer still more or less coincided with those of the irrigated rice area of the Grand Prairie. Its contours, however, had shifted over the past decade and had become closer together, indicating that water levels in the most severely affected locations continued to decline faster than those in the surrounding areas. Indeed, in the area of Stuttgart and Almyra, near the center of the cone, water levels had declined twenty-five feet

\footnotetext{
${ }^{48}$ Rules for the Protection and Management of Ground Water, Title IV (Little Rock: Arkansas Soil and Conservation Commission, 2001); C. R. Nestrud and T. Paulson, Arkansas Handbook on Environmental Laws, $2^{\text {nd }}$ ed. (Rockville, MD: Government Institutes, 1998).

${ }^{49}$ Engler, Bayey, and Sniegocki, "Artificial Recharge, Grand Prairie Region, Environment and History," 27-32.

${ }^{50}$ Daniel, Breaking the Land, 271-273; M. W. Slusher and Troy Mullins, "Mechanization of the Rice Harvest," Arkansas Agricultural Experiment Station Report Series 11 (August 1948): 4.

${ }^{51}$ Engler, Bayey, and Sniegocki, "Artificial Recharge, Grand Prairie Region, Environment and History," 16.
} 
since 1929. In places closer to the cone's perimeter like Gillett and Bayou Meto, the level had declined only five feet. ${ }^{52}$

With rice prices relatively high and pump equipment frequently needing to be lowered farther into the ground, the potent southern rice lobby asked for federal help with the water problem in the Grand Prairie. On December 18, 1945, the Committee on Flood Control of the U.S. House of Representatives directed the Army Corps of Engineers to review some previous reports concerning the water supply for irrigation. ${ }^{53}$ The Corps responded with a study of the feasibility of importing water from the White River at a point near DeValls Bluff, for distribution by a series of canals throughout the prairie. ${ }^{54}$

In 1948, the Corps submitted to Congress an engineering plan for the Grand Prairie region designed to strengthen flood control, improve drainage from agricultural land, and supply farms with additional irrigation. The report argued that the three needs were closely related and that the White River diversion component was an integral part of the plan. Local interests were to pay 60 percent of water supply costs, and the Corps predicted benefits would exceed costs by a factor of 2.51 . The proposal included letters of support from Secretary of Agriculture Charles F. Brannan and Arkansas governor Ben Laney and a strongly worded letter of disapproval from Secretary of the Interior J. A. Krug, indicative of the fledgling competition for irrigation projects between the Army Corps of Engineers and the Bureau of Reclamation. ${ }^{55}$

If completed, the project would have alleviated the irrigators' reliance on dwindling groundwater supplies but not without damaging nearby wetlands and subjecting irrigators to government water contracts as well as rippling economic and environmental side effects. Congress authorized the plan in the Flood Control Act of 1950, marking the first attempt to address the Grand Prairie irrigation issue with a large-scale engineering solution. ${ }^{56}$

The approval of this plan seemed to mark a new phase in the development of irrigation in the Grand Prairie. Opinions have been divided on

\footnotetext{
${ }^{52}$ Engler, Thompson, and Kazmann, "Ground Water Supplies for Rice Irrigation in the Grand Prairie Region, Arkansas," 30-33.

${ }^{53}$ Engler, Bayey, and Sniegocki, "Artificial Recharge, Grand Prairie Region, Environment and History," 27-29.

${ }^{54} \mathrm{R}$. W. Crawford et al., Report of the Mississippi River Commission: Review of Reports, White and Arkansas Rivers and Tributaries with Reference to the Grand Prairie Region, Arkansas (Washington: Government Printing Office, 1948).

${ }^{55}$ Engler, Bayey, and Sniegocki, "Artificial Recharge, Grand Prairie Region, Environment and History," 29; U.S. Congress, House, White and Arkansas Rivers and Tributaries, Grand Prairie Region, Arkansas, 81 ${ }^{\text {st }}$ Cong., $1^{\text {st }}$ sess., 1948, H. Doc. 255.

${ }^{56}$ Flood Control Act of 1950, U.S. Statutes at Large, vol. 62, pt. 1, 1950, 174.
} 
the project since it was first proposed, and, nearly sixty years later, proposals for the diversion of White River water continue to be bitterly debated and litigated in Arkansas. Federal approval has been granted to the Grand Prairie Area Demonstration Project, a U.S. Army Corps of Engineers plan not unlike the one approved in 1950, which would allow for continued irrigated rice production without substantial reductions in acreage. The plan calls for increased conservation, irrigation efficiency, and on-farm storage reservoirs, but its main feature involves the diversion of water from the White River, at a rate of 1,640 cubic feet per second, to rice fields and storage facilities though a distribution system of pumping stations, canals, pipelines, and streams. ${ }^{57}$

At present, there is substantial opposition to this project on a number of grounds. Environmentalists are alarmed about the potential impact to the White River ecosystem and the nearby White River and Cache River National Wildlife Refuges. ${ }^{58}$ Hunting-related businesses and organizations fear the project may harm the region's lucrative duck hunting industry by altering or destroying wetland habitats. ${ }^{59}$ Others oppose it on economic grounds, disapproving of a $\$ 1,525$ per irrigated acre benefit to an already heavily subsidized industry. ${ }^{60}$ Significantly, many of the region's rice farmers have expressed strong reservations, including concerns over water contracts and use of arable land for project infrastructure as well as fears that dependence on imported water may decrease land values. ${ }^{61}$ Meanwhile, farmers have been rotating rice with less water-intensive crops and have employed a variety of conservation techniques to slow the falling water table.

The Grand Prairie rice industry is certain to undergo major changes in the coming years. The region has been designated a "critical groundwater area" by the Arkansas Soil and Water Conservation Commission, and, according to current predictions, without remedial action the Mississippi Alluvial Aquifer's capacity to support irrigation or other uses in the Grand

\footnotetext{
${ }^{57}$ U.S. Army Corps of Engineers, Grand Prairie Area Demonstration Project General Reevaluation Report (1999), www.mvm.usace.army.mil/grandprairie (accessed September 2, 2005).

${ }^{58}$ Douglas Jehl, "Arkansas Farmers Run Dry, and U.S. Remedy Sets off Debate," New York Times, November 11, 2002.

${ }^{59}$ American Fisheries Society, "Towards Sustainability on Arkansas' Grand Prairie," 2003, www.sdafs.org/arkafs/arafs.htm (accessed September 2, 2003).

${ }^{60}$ White River Irrigation District, Grand Prairie Area Demonstration Project Rumors and Facts (Stuttgart, AR: n.p., 2003).

${ }^{61}$ Arkansas Democrat-Gazette (Little Rock), August 24, November 16, 2001.
} 
Prairie will be severely diminished by $2015 .^{62}$ It is likely that irrigators will soon have to yield their independence in the acquisition of water or significantly reduce rice acreage in favor of less consumptive crops. Regardless of which sources and methods of crop irrigation prevail in the coming years, there is no doubt that they will substantially affect the economy and environment of the region, as they have throughout the history of the industry.

${ }^{62}$ John B. Czarnecki, Philip D. Hays, and Paul W. McKee, "The Mississippi River Valley Alluvial Aquifer in Arkansas: A Sustainable Water Resource?" U.S. Geological Survey Local Reports FS-041-02 (2002); Arkansas Soil and Water Conservation Commission, "Groundwater Protection and Management Report," 2002, http://www.aswcc.arkansas.gov/beauDraft_for_2003-04_WC2.pdf (accessed September 6, 2004), 20. 